NBER WORKING PAPER SERIES

\title{
RACE, SEGREGATION, AND POSTAL EMPLOYMENT: NEW EVIDENCE ON SPATIAL MISMATCH
}

\author{
Leah Platt Boustan \\ Robert A. Margo \\ Working Paper 13462 \\ http://www.nber.org/papers/w13462
NATIONAL BUREAU OF ECONOMIC RESEARCH
1050 Massachusetts Avenue
Cambridge, MA 02138
October 2007

We appreciate the helpful suggestions of two referees, Nathaniel Baum-Snow, Lee Breckenridge, William Collins, Patrick Flaherty, Lawrence Katz, Christopher Rohlfs, Stuart Rosenthal, Steven Ross, Jesse Rothstein, and of workshop participants at Boston University, the National Bureau of Economic Research, New York University, Northwestern University, the Rand Corporation, Syracuse University, University of California-Berkeley, University of California-Los Angeles, University of California-Merced, University of Connecticut, University of Rochester, and the annual meetings of the American Economic Association and the Society of Labor Economists. Excellent research assistance was provided by Nahuel Costilla, Angelina Morris, Nelson Oliver, and Mingjie Sun. We thank the Richard S. Ziman Center for Real Estate at UCLA for financial support. The views expressed herein are those of the author(s) and do not necessarily reflect the views of the National Bureau of Economic Research.

(C) 2007 by Leah Platt Boustan and Robert A. Margo. All rights reserved. Short sections of text, not to exceed two paragraphs, may be quoted without explicit permission provided that full credit, including (C) notice, is given to the source. 
Race, Segregation, and Postal Employment: New Evidence on Spatial Mismatch

Leah Platt Boustan and Robert A. Margo

NBER Working Paper No. 13462

October 2007, Revised August 2008

JEL No. J71,N32,N92

\begin{abstract}
The spatial mismatch hypothesis posits that employment decentralization isolated urban blacks from work opportunities. This paper focuses on one large employer that has remained in the central city over the twentieth century - the U.S. Postal Service. We find that blacks substitute towards postal work as other employment opportunities leave the city circa 1960. The response is particularly strong in segregated areas, where black neighborhoods are clustered near the central business district. Furthermore, this pattern only holds for non-mail carriers, many of whom work in central processing facilities. More recently, the relationship between black postal employment and segregation has declined, suggesting that spatial mismatch has become less important over time.
\end{abstract}

Leah Platt Boustan

Department of Economics

8283 Bunche Hall

UCLA

Los Angeles, CA 90095-1477

and NBER

lboustan@econ.ucla.edu

Robert A. Margo

Department of Economics

Boston University

270 Bay State Road

Boston, MA 02215

and NBER

margora@bu.edu 


\section{Introduction}

In the early twentieth century, manufacturing plants and related low- and mid-skill level jobs located near central business districts to take advantage of railroads and other transportation nodes. Black migrants to urban areas settled in residential enclaves close to these employment opportunities in this period (Taeuber and Taeuber, 1965; Farley, 1968). After the Second World War, firms began relocating from central cities to the suburban ring (Glaeser and Kahn, 2001). While white households could - and did - readily follow jobs to the suburbs, African-Americans initially faced strong barriers to suburban residence. As a result, segregation became increasingly synonymous with the residential centralization of black neighborhoods in otherwise employment-decentralized metropolitan areas. In a famous paper, Kain (1968) argued that this “spatial mismatch" worsened employment outcomes for African-American labor, thereby harming the prospects for black economic progress.

This paper provides a novel test of spatial mismatch. We examine the historical evolution of racial differences in employment at the United States Postal Service (USPS), an employer whose large processing and distribution plants remained centralized long after other firms left downtown areas. Specifically, we investigate whether black postal employment increased as other job opportunities disappeared from central cities. To control for other forces changing black employment patterns over this period (such as rising educational attainment), we compare postal employment in more- and less-segregated metropolitan areas; in segregated areas, black residents live farther from suburban job openings. We also use white workers as a control group to adjust for general effects of residential segregation; for example, segregation may lead to the inefficient duplication of public infrastructure. Our main analysis is thus a triple-difference, 
comparing black and white postal employment rates between more- and less- segregated areas over time.

Residential segregation was unrelated to the relative odds of black postal employment in 1940 or 1950, when centrally-located jobs were plentiful. In 1960 and 1970, as firms began relocating to the suburban ring, a large positive correlation between segregation and black postal employment emerges. After 1970, this relationship weakened but, as recently as 2000 , was still positive and statistically significant. This attenuation is consistent with the changing nature of residential segregation, which no longer solely occurs between black cities and white suburbs, but now incorporates black neighborhoods in the suburban ring. Our results suggest that spatial mismatch was an important force in 1960 and 1970 but became less potent over time as black households gained access to the suburbs.

We interpret the time series pattern as evidence that black workers substituted toward postal employment as jobs disappeared from the central city. We test this proposition further in a cross-section of metropolitan areas, finding that blacks are more likely to work for the postal service in areas with decentralized employment. We also exploit a distinction between occupations in the postal service: mail carriers tend to work throughout the metropolitan area, while clerks, whose primary task is to process inter-city mail, are concentrated downtown. Consistent with our emphasis on job access, the relationship between residential segregation and postal employment is only found for non-mail carriers.

We also conduct a number of robustness tests to probe the sensitivity of our basic findings. While we treat non-carrier postal work as a prototypical example of a centrally-located job, we find a similar relationship between segregation and black employment in other highly centralized public sector occupations ca. 1970. Our results are robust to changing the sample 
parameters (for example, including non-workers); measuring segregation for the central city alone; including additional city or metropolitan area covariates; and restricting the analysis to young workers to minimize the selection bias induced by migration across urban areas.

This paper introduces two innovations to the spatial mismatch literature. Our first contribution is the emphasis on occupational choice. Previous studies have focused on black employment or labor force attachment (Ellwood, 1986; Ilhanfeldt and Sjoquist, 1990; Rogers, 1997; Raphael, 1998; Hellerstein, Neumark and McInerney, 2007). ${ }^{1}$ These measures introduce a well-recognized omitted variables problem. Within metropolitan areas, residents who are, for unobservable reasons, less attached to the labor force might sort into neighborhoods that are farther from job opportunities. One solution to this problem has been to use variation across metropolitan areas, which minimizes (but does not eliminate) the possibility of sorting (Ihlanfeldt and Sjoquist, 1989; Weinberg, 2000; Weinberg, 2004). We propose another solution: identify an outcome that is associated with spatial mismatch but is otherwise unlikely to be positively correlated with the propensity to live in isolated neighborhoods. We argue that working for the postal service, a well-paid, civil service job that, for historical reasons, has remained in downtown areas, is an excellent candidate.

Our second innovation is an historical perspective. Most studies of spatial mismatch rely on data for a single cross section or short period of time. By design, these cannot reveal when spatial mismatch first became a problem or whether the importance of mismatch intensified or waned over time in response to changes in the ability of blacks to access suburban employment. We compile data from 1940 to 2000 and, by observing changes in black occupational choices as employment decentralized, are able to "trace out" an economic history of spatial mismatch.

\footnotetext{
${ }^{1}$ Exceptions include Taylor and Ong (1995), Gabriel and Rosenthal (1996), and Ross (1998) who investigate commuting times and residential mobility.
} 


\section{Residential Segregation in Historical Context}

Prevailing wisdom about the likely effect of residential segregation on black economic outcomes has shifted over the century. In the 1920s and 1930s, scholars argued that residential segregation provided a protected market for African-American professionals and shop owners who served an overwhelmingly black clientele (W.E.B. Dubois, 1967 [1899]; E. Franklin Frazier, 1957; Abram Harris, 1936; Gunnar Myrdal, 1944; Carter Woodson, 1934). After the wave of urban riots in the 1960 s, policymakers and community leaders continued to actively debate the relative benefits of segregation versus integration (Downs, 1968; Kain and Persky, 1969; Levine, 1972). By contrast, many scholars now blame residential segregation for the persistence of concentrated pockets of black poverty (Wilson 1987; Massey and Denton, 1993; Cutler and Glaeser 1997; Collins and Margo 2000).

The timing of this reversal of opinion broadly coincides with the departure of many large employers from central cities. ${ }^{2}$ During the first half of the century, employment remained heavily concentrated in the central business district, even as population began to disperse to early street car suburbs and later to bedroom communities accessible by car (Warner, 1978; Jackson, 1985). Case studies of particular cities suggest that employment decentralization was underway by the early 1950s (Fogelson, 2001, pp. 381-394). ${ }^{3}$ The Census Bureau began gathering data on work locations in 1960. The share of metropolitan area residents who worked in the center city fell perceptibly over the next decade from 59.3 percent in 1960 to 51.7 percent in 1970. By 2000, only 42.3 percent of the metropolitan workforce remained in the center city.

\footnotetext{
${ }^{2}$ In making this point, we are not asserting that center city job loss cum spatial mismatch contributed to the emergence of "bad ghettos," only that the two are temporally associated. See Cutler and Glaeser (1997) and Collins and Margo (2000) for econometric evidence relating segregation to black outcomes.

${ }^{3}$ Baum-Snow (2007) calculates that, in 1950, 64 percent of employment in manufacturing, retail and wholesale trade, and business/repair services was located in central cities, compared to 61.8 percent in 1960 . These sectors were more concentrated than average, so levels for the whole workforce were slightly lower.
} 
Before 1970, few African-American households lived in the suburbs, even if they could afford to do so. Initially, many suburban neighborhoods were covered by restrictive covenants, which prevented the transfer of property to African-Americans and members of other groups (Brooks, 2002). Even after the legal enforceability of such covenants was struck down by the Supreme Court in the late 1940s, black suburbanization was slowed by the intimidation and violence of white residents and the discriminatory behavior of realtors and financial institutions (Sugrue, 1996; Ross and Yinger, 2002; Stuart, 2003). Early state-level fair-housing laws were largely ineffective in combating these tactics (Collins, 2004).

Blacks began to move to the suburbs in earnest after the passage of federal fair housing legislation in 1968. While, in 1960, 84.8 of African-Americans in metropolitan areas lived in the central city, this share fell to 68.1 by $1980 .^{4}$ As a result, the problem of spatial mismatch was likely most acute in the 1950s and 1960s, when employment had started to decentralize, but black households were yet unable to follow.

\section{The Location and Racial Composition of Postal Employment}

The US Postal Service has long been one of the nation's largest civilian employers, and it is the only employer with separate industry and occupation codes in the federal Census (Bureau of Labor Statistics, 2007). Virtually all postal jobs are subject to civil service rules requiring individuals to pass an exam in order to qualify for employment. When a job becomes available, hiring officers must choose from the three top-scoring candidates (the so-called "Rule of Three") subject to some restrictions on veteran status. ${ }^{5}$

\footnotetext{
${ }^{4}$ The change may understate the actual extent of black suburbanization if central city boundaries expanded due to annexation.

${ }^{5}$ Specifically, among the top three candidates veteran status trumps rank. If the top candidate is a veteran, he or she must be chosen; if the second ranked candidate is a veteran, the third ranked candidate cannot be selected.
} 
Figure 1 portrays the share of men employed by the postal service over the century. For comparison, we also show the share of men who worked in the remainder of the one-digit industry "public administration." Around one percent of the white male labor force was employed in the postal service throughout the century. In contrast, black postal employment increased dramatically from one to 2.5 percent between 1940 and 1970 , a rate faster than the general growth in public employment. The timing of this growth broadly corresponds to black migration to urban areas and the beginning of employment decentralization.

From 1970 onward, the odds of postal employment have been falling for all men. This decline may reflect the introduction of ZIP codes in 1963. The resulting automation of mail processing allowed substantial substitution of capital for labor. Private sector substitutes for the postal service (for example, Federal Express and United Parcel Service) and the rise of various forms of electronic communication, such as email and cellular phones, may have also contributed to this decline in recent years.

While blacks are twice as likely as whites to work for than postal service nationwide, in some cities, this disparity was twice or three times as large. Figure 2 presents the share of black and whites in the full-time, full-year labor force who were employed at the USPS by metropolitan area in 1970. The white share fluctuates between one and two percent across the country. By contrast, in some cities - with San Francisco, Chicago, and Indianapolis most prominent among them - the share of blacks working for the postal service was as high as 7.5 percent, an extraordinarily large (and, to our knowledge, previously unnoticed) racial disparity.

\footnotetext{
${ }^{6}$ The "public administration" industry covers public employees whose occupations are considered by the Census Bureau to be "intrinsic" to the public sector. Thus, for example, public school teachers are classified as working in educational services rather than public administration because teachers can work for either a public or a private school. From 1940 onward, the Census uses the "class of worker" variable to identify all public sector employees regardless of their specific occupation. Appendix Table 1 presents the number of men by race employed in the entire public sector from 1940-2000, along with the intrinsic public employees depicted in Figure 1. These intrinsic employees make up 40 percent of the total public sector, and their growth mirrors that of the sector as a whole.
} 
The over-representation of African-Americans in postal employment may be due to the retention of mail processing facilities in downtown areas, near black neighborhoods, even as similar warehousing and wholesale operations moved to the suburbs. The centralization of mail processing dates from the early twentieth century, when the bulk of intercity mail was transported by rail. ${ }^{7}$ At the time, central post offices were built in the heart of the central business district near the main rail terminal. Intercity mail was collected at this central facility, loaded on the train, and sorted en route (into cubbyholes) by highly trained railway mail clerks.

Railway mail waned after the 1920 s, a casualty of advances in trucking and air transportation. The last rail route between New York City and Washington, DC ceased operations in 1977. Given that population and businesses - that is, the demanders and suppliers of mail delivery - have moved to the suburbs and that the mail itself no longer travels by rail, it would seem economically sensible that mail processing and distribution, too, would move out of the central city. However, the postal authorities face a number of regulatory impediments to the relocation of their main facilities. As one example, the National Environmental Policy Act (1969) requires that federal agencies prepare an environmental impact statement, including a consideration of local job loss, before undertaking any "major federal action," including the relocation of a large postal processing plant. ${ }^{8}$ Local politicians and postal unions also routinely oppose site relocation.

As a result, mail processing and distribution has continued apace in central cities. Table 1 presents evidence on the geographic location of postal jobs. The first panel uses place of work

\footnotetext{
${ }^{7}$ Our discussion of the history of mail processing and distribution is based on United States Postal Service (2003).

${ }^{8}$ The case precedent on postal processing and distribution centers was established in City of Rochester v. U.S. Postal Service, 541 F.2d967. In the early 1970s, the city of Rochester sued the postal service over its plan to shutter its downtown facility. The court found that closing the Rochester postal facility constituted a "major federal action," and further added that the "environmental impact" of an action must include any socioeconomic consequences - for example, job loss - that might ensue. Despite these findings, the court ruled against the city on technical grounds, and the Rochester center was relocated to the suburbs.
} 
data from the 1970 Census to compare the job locations of postal employees with the rest of the workforce. Around half of the private and (non-postal) public sector employees remained downtown in that year. Mail carriers were similarly distributed between the city and the suburbs. By contrast, 71 percent of non-carrier postal employees worked in the city. ${ }^{9}$ Indeed, nearly one in five such postal employees worked in the central business district, compared to one in twelve workers in the private sector. ${ }^{10}$

To further document the location of mail processing activities, we mapped the street addresses of the 237 Processing and Distribution Centers (P\&DCs) in the 2007 Postal Directory. ${ }^{11}$ The second panel of Table 1 displays characteristics of the neighborhoods in which these facilities are located. ${ }^{12}$ Eighty percent are in the central city. The average black population share in a facility neighborhood is 38 percent, compared with 28 percent in the surrounding county. Even more striking is the fact that the typical facility is located in a neighborhood that is physically adjacent to at least one census tract that is majority black. The maximum black population share for a tract in the typical facility neighborhood is 64 percent.

Unlike other centrally-located jobs with modest skill requirements, postal work offers high salaries and good benefits. Gosnell (1935, p. 305) reported that, in the late 1920s, black postal workers were “among the best livers [on] Chicago's south side." This rosy picture is consistent with nationally representative Census data, which are presented in Appendix Table 2. In 1940, 14 percent of all blacks earning above the national median worked for the postal

\footnotetext{
${ }^{9}$ Over two-thirds of non-carrier postal employees are classified as "clerical, n.e.c."; these include workers at both retail post offices and at processing and distribution facilities. The other large occupation groups include postmasters, laborers, janitors, and truck drivers.

${ }^{10}$ Despite overall decentralization, this disparity in job location was still present in 2000.54 percent of other postal employees worked in the central city, compared to 38 percent of mail carriers and 42 percent of all private sector workers.

${ }^{11}$ We exclude 55 facilities that can be clearly identified as supplementary Airport Mail Centers.

${ }^{12}$ The facility neighborhood is defined as its own Census tract and all adjacent tracts. Addresses were mapped using www.socialexplorer.com. Means are weighted by the black population share in the county.
} 
service. ${ }^{13}$ The earnings of the average black postal worker placed him in the top five percent of the black weekly wage distribution and at the $70^{\text {th }}$ percentile of the non-black distribution in that year. By 2000, the mean black postal worker remained in the top 25 percent of black earners and above the median for the nation as a whole.

\section{Data, Estimation Strategy and Empirical Results}

We examine the changing relationship between segregation and black postal employment by pooling Census data from 1940 to 2000 and estimating regressions of the form:

$$
\text { Postal }_{\mathrm{ijt}}=\alpha_{\mathrm{j}}+\Sigma_{\mathrm{t}} \beta_{\mathrm{t}}\left(\text { Black }_{\mathrm{ijt}}+\Sigma_{\mathrm{t}} \gamma_{\mathrm{t}}\left(\text { Segregation }_{\mathrm{jt}}\right)+\Sigma \delta_{\mathrm{t}}\left(\text { Black }_{\mathrm{ijt}} \cdot \text { Segregation }_{\mathrm{j} \mathrm{t}}\right)+\Phi_{\mathrm{t}}+\Omega \mathrm{X}_{\mathrm{ijt}}+\varepsilon_{\mathrm{jjt}}\right.
$$

where $i$ and $j$ index individuals and metropolitan areas, respectively, and $t$ indexes Census year. Posta $\mathrm{l}_{\mathrm{ijt}}$ is an indicator equal to one for postal employees. The coefficients of interest $\left(\delta_{\mathrm{t}}\right)$ are yearspecific interactions between a metropolitan area's level of segregation and an indicator for an individual's race. If $\delta_{\mathrm{t}}$ is positive, blacks in segregated areas are more likely to work for the post office, relative to their white counterparts, in year $t$. Under the spatial mismatch hypothesis, we expect $\delta_{\mathrm{t}}$ to be close to zero in 1940 and 1950, before other employment left the city, and to be positive from 1960 onward as the post office becomes, in many cases, the only good job in proximity to black neighborhoods. As black households gain increasing access to the suburbs, the relationship between segregation and postal work may diminish.

The other controls adjust for the main effects of race, segregation and Census year. In some specifications, we directly include a decade-specific measure of local residential

\footnotetext{
${ }^{13}$ Black postal workers had disproportionately high levels of education in 1940. 28.1 percent of black postal workers had at least some college education, compared to 4.9 percent of the black population as a whole. In part because of their high wages and educational attainment, black postal workers played an important role in black community life (Rubio, 2006).
} 
segregation alongside a single metropolitan area fixed effect. In others, we estimate a vector of time-varying metropolitan area fixed effects, which absorbs the main effect of segregation and any other correlated local characteristics. ${ }^{14}$ Standard errors are clustered to allow for correlated errors at the metropolitan area level. ${ }^{15}$

The micro-Census data are taken from the Integrated Public Use Microdata Series (IPUMS) (Ruggles, et al., 2008). We construct a sample of men and women between the ages of 18 and 64 who worked full time for the full year in the non-farm economy. ${ }^{16}$ Later, we demonstrate that the results are robust to excluding women or including part-time workers and the unemployed. We cannot include 1960 in the main analysis because metropolitan areas are not identified in the micro data in that year; we conduct a comparable state-level analysis below.

We measure residential segregation using the dissimilarity index, which is defined at the metropolitan area level as:

$$
1 / 2 \Sigma_{n} \mid\left[\left(\text { black }_{n} / \text { black }_{\text {total }}\right)-\left(\text { non-black }_{n} / \text { non-black }_{\text {total }}\right)\right] \mid \text {. }
$$

Black $_{\text {total }}$ is the number of black residents in the entire metropolitan area, while black ${ }_{n}$ counts black residents in a given Census tract (neighborhood). ${ }^{17}$ The index takes on a value of zero when each neighborhood mirrors the racial composition of the metropolitan area as a whole and a value of one in a perfectly segregated SMSA. The dissimilarity index does not explicitly

\footnotetext{
${ }^{14}$ Year-specific metropolitan area fixed effects will also implicitly control for any boundary changes to the central city or the metropolitan area over time due to annexation or expansion along the periphery.

${ }^{15}$ We also add a full vector of individual controls $\left(\mathrm{X}_{\mathrm{ij}}\right)$, including a fourth degree polynomial in age, and a series of dummies equal to one if the individual is female, married, a veteran or foreign born. Educational attainment is measured as highest grade completed; in 1990 and 2000, we use the IPUMS education recode. We include dummies for the following categories of completed schooling: 0-8, 9-11, 12, 13-15, and 16 or more years. All personal characteristics are interacted with the race dummy. The 1950 regression includes only sample line individuals. ${ }^{16}$ Full-time, full-year workers are individuals who work both 40 hours a week and 40 weeks during the year. We exclude those who are currently enrolled in school, living in group quarters, or in the armed services.

${ }^{17}$ In 1940 and 1950, the index reflects segregation within the central city, while the indices for 1960-2000 are calculated at the metropolitan area level. For comparison, we construct a city-level segregation index for 1970 (see Table 8, column 3).
} 
measure black residential centralization. In theory, a segregated city could be divided down the middle, with blacks living on one side of the central business district and whites living on the other; however, this scenario is highly at odds with the history of American urban development. We demonstrate below that black postal employment is also correlated with direct measures of centralization. Summary statistics for the individual and metropolitan area level variables are presented in Appendix Table 3.

\section{Empirical Results: IPUMS estimates}

Table 2 reports the coefficients of interest from various specifications of equation 1. Panel A contains a single metropolitan area fixed effect, which allows us to estimate the main effect of segregation on postal employment. Panel B instead estimates a separate metropolitan area fixed effect in each year. In both panels, we find no meaningful relationship between segregation and the relative probability of black postal employment in 1940 or $1950 .{ }^{18}$ When employment opportunities remained in the central city, living in a more segregated metropolitan area did not encourage blacks to pursue postal work.

In contrast, by 1970, blacks in segregated area were more likely to be employed in the postal service. A one standard deviation increase in the metropolitan dissimilarity index is associated with a 1.4 point increase - or a doubling - in the probability of black postal employment $(=0.12 \cdot 0.117)$. The size of this relationship declines from 1970 to 2000 , but remains statistically and economically significant in each year. The magnitude of the coefficient in 1970 is compatible with what we know about the extent of job loss from the central city between 1950 and 1970. In 1950, around 60 percent of metropolitan jobs were located in the

\footnotetext{
${ }^{18}$ In 1940, neighborhood population counts were conducted at both the tract- and the ward-level. Ward level data is available for 82 metropolitan areas. We find a similar relationship between segregation and postal work when using ward-level geography (coeff. $=0.011$; s.e. $=0.011$ ).
} 
central city; this share fell to 52 percent by 1970 (see footnote 3). In a metropolitan area with 100,000 workers, a decline of this size translates into the loss of 8,000 city positions. If job loss was proportional to the racial composition of the typical urban workforce, 800 "black" jobs - or 10 percent of the total - would have been lost to the suburbs. In the average city in 1970, 2.5 percent of the black workforce, or 130 black workers in this example, were employed at the postal service. An increase in residential segregation would result in an additional 130 black workers at the postal service, or 16 percent of all those whose jobs moved to the suburban ring.

The number of metropolitan areas that can be identified in the micro data and for which the data exist to calculate a segregation index varies from 45 in 1940 to 243 in 2000 . We are concerned that changes to the sample composition may contribute to fluctuations in the point estimates over time. Panel C conducts a parallel analysis for the 45 metropolitan areas that can be consistently identified in each decade. The basic relationship between segregation and postal employment is unchanged, but the coefficients are between 15 and 40 percent smaller.

Given the similarity of the results in the full and reduced samples, we verify that the relationship between segregation and postal work is not being driven by a few outliers. Figure 3 plots the differential probability of postal employment (black versus white) against residential segregation in 1970. The postal probabilities are regression-adjusted for the full set of individual characteristics. The figure suggests that the positive relationship between segregation and black postal employment is a general phenomenon, rather than being driven by a single city like Chicago that is both highly segregated and has a large concentration of black postal workers.

All results thus far have been estimated using a sample of full-time, full-year employees. The relationship between segregation and black postal employment may be attenuated in a sample that includes part-time workers and the unemployed. The share of all adults engaged in 
postal work can be expressed as $\{\operatorname{pr}($ employed $) \cdot \operatorname{pr}(\operatorname{postal} \mid$ employed $)\}$. If segregation is associated with low black employment rates, the first term in this expression will decrease, potentially obscuring the relationship of interest (Cutler and Glaeser, 1997). Table 3 demonstrates that the relationship between segregation and postal employment is robust to this concern. The regressions in the first row include all adults. The coefficients are 20 to 25 percent smaller than for the full-time, full-year sub-sample, but remain significant and large. Reading down the rows, the table adds incremental employment restrictions to the sample. The relationship between segregation and postal employment slowly grows to match the preferred sample in the last row.

There is a dramatic increase in the relationship between segregation and black postal employment between 1950 and 1970. One concern is that specific events during the 1960s including urban riots, the return of veterans from Vietnam, and a large reorganization of the postal service late in the decade - could be responsible for this change. Finding a similar relationship in 1960 would cast doubt on these decade-specific alternatives. Because the 1960 IPUMS does not report metropolitan area of residence, we cannot estimate equation 1 in this year. However, the 1960 IPUMS does report state of residence. Table 4 pools data from 19402000 and conducts an analogous state-level regression, in which a state's segregation index is calculated by weighting the dissimilarity indices of cities in that state by population. As in the metropolitan area regression, segregation has no effect on black postal employment in 1940 or 1950, but strongly increases the probability of working for the postal service in 1960. In fact, the coefficients in 1960 and 1970 are not statistically distinguishable from each other and the 1970 coefficient is similar to the estimate in the main metropolitan area level regression (Table 2, 
column 3). As before, the relationship between segregation and black postal employment attenuates between 1970 and 2000 .

\section{Direct Measures of Job Access and Employment Decentralization}

From 1960 to 2000, relative black employment in the postal service was higher in segregated metropolitan areas, where black residence was likely to be concentrated downtown. This timing is consistent with our interpretation that centrally-located black workers substituted toward postal work as other jobs left the central city. In this case, we would expect to find the same phenomenon in a cross-section of metropolitan areas. Specifically, we should observe more black postal employment in areas where the majority of employment opportunities are located in the suburban ring.

The most comprehensive combination of place of work and place of residence data is available in the 1980 IPUMS. ${ }^{19}$ The first panel of Table 5 demonstrates that blacks were more likely to work for the postal service in areas where employment was decentralized or where black residence was highly concentrated in the central city in that year. The second column interacts residential segregation and the share of employment in the central city. We expect segregation to have a smaller effect on black postal employment in areas in which centrallylocated employment options are plentiful - and, indeed, we find this pattern. To interpret the magnitude of this interaction, consider the mean metropolitan area in 1980, in which 55 percent of employees work in the central city. In this case, complete segregation (dissimilarity equal to one) would have a large positive impact on black postal employment (coeff. $=0.051)$. Increasing the share of downtown employment to 71 percent (or one standard deviation) would reduce the

\footnotetext{
${ }^{19}$ In 1970, either metropolitan area of residence or place of residence within the metropolitan area (city versus suburb) is identified, but not both. Neither 1990 nor 2000 distinguishes between working in the central business district from working in the remainder of the central city.
} 
impact of segregation on black postal employment considerably (coeff. $=0.016$ ). This finding is consistent with our reading of the time series pattern. Residential segregation only encourages blacks to substitute towards postal employment when other centrally-located jobs are scarce.

The second panel of Table 5 examines the relationship between black postal employment and a direct measure of racial residential centralization. The centralization index measures the cumulative proportion of blacks relative to whites who live within concentric bands around the central business district. ${ }^{20}$ Higher values of the centralization index are significantly associated with relative black postal employment (column 1). The centralization index, while a more direct measure of black residential concentration, is highly correlated with the dissimilarity index (column 2).

\section{Comparing Mail Carriers to Other Postal Employees}

Thus far, our analysis has examined the entire postal workforce. However, within the postal service, only postal clerks tend to work downtown, while mail carriers are distributed throughout the metropolitan area (Table 1). If residential segregation limits blacks' access to suburban jobs, we should see a stronger relationship between segregation and employment in non-carrier positions. Furthermore, this pattern should not be specific to the post office - rather, segregation should increase black employment in any public sector occupation that tends to be concentrated in central cities.

Table 6 presents results from seemingly unrelated regressions in which the dependent variables are indicators for working as a mail carrier, as a non-carrier postal employee, or as a public employee in an occupation whose members are more/less likely to work in the central city. We divide occupations in the public sector into those that are above and below median for

\footnotetext{
${ }^{20}$ See Galster (1984) for a comparison of this index to other measures of centralization.
} 
the share of workers employed in the central city. ${ }^{21}$ Bus drivers and subway conductors are the most centralized occupations, while teachers are among the most decentralized. ${ }^{22}$

We present the main coefficient of interest (the interaction between segregation and a race dummy) for three decades that span the period. In 1940, living in a segregated city does not increase the probability of a black resident working for the postal service in any capacity. In contrast, by 1970, segregation becomes positively associated with postal work, but only for the non-carriers, who tend to work in the central city. The probability of working as a mail carrier, a job that is evenly distributed between city and suburb, has no meaningful relationship with segregation in any year. In 1970, other public occupations follow a similar pattern. Segregation increases the share of African-Americans working in centralized public occupations and decreases the share working in decentralized occupations. By 2000, the distinction between centralized and decentralized public occupations disappears.

Our comparison of occupations within the postal sector rules out alternative explanations based on general changes to either the postal service or public employment - including the formal recognition of postal unions by the federal government in the early 1960s or the Civil Rights movement. There is no reason to believe that these changes should have differentially affected particular occupations within the public sector.

Furthermore, the distinction between mail carriers and other postal employees challenges explanations based on private sector racism. Suppose that a city's level of residential segregation were correlated with the propensity of its employers to discriminate on the basis of race. ${ }^{23}$ In this

\footnotetext{
${ }^{21}$ The median is calculated by first weighting each occupation by its number of white, metropolitan employees.

${ }^{22}$ In 1970, 67 percent of employees in above-median public occupations worked in the central city. This share is somewhat lower than postal clerks (71 percent) but provides a reasonable comparison group.

${ }^{23}$ If the correlation between segregation and local racism is a long-standing one, this story would not be consistent with the lack of a segregation-postal employment relationship in 1940 and 1950. One could imagine, however, that racism was widespread at mid-century and has been slowest to decline in segregated areas.
} 
case, employers in segregated cities may underpay their black workers, either to satisfy their own tastes or those of their customers (Becker, 1971). However, the unobserved racism hypothesis predicts a positive relationship between segregation and all forms of public employment. Instead, we find that segregation is only correlated with forms of public employment that tend to be concentrated in the central city.

\section{Additional Robustness Checks}

Tables 7 and 8 provide several additional robustness checks. The results are robust to reweighting the data; measuring segregation at the city - rather than metropolitan area - level; separately identifying the effect of initial segregation and changes in segregation; and adding a series of covariates that are correlated with area segregation. The first column of Table 7 reproduces the coefficient from our preferred specification in 1970. Because we use individual level data, our regressions are, in effect, weighted by the population size of each metropolitan area. Results are qualitatively similar if we instead weight each metropolitan area equally (column 2).

The dissimilarity index is based on race-specific population counts by Census tract. In 1940 and 1950, the Census Bureau only defined tracts within central cities, while, from 1960 onward, tract data is available in the suburbs as well. This measurement difference could account for the sharp increase in the relationship between segregation and black postal employment between 1950 and 1960. For comparison, we calculate a new dissimilarity index for 1970 using only central city tracts. The city- and metropolitan area-level indices are highly correlated (corr. $=0.78$ ). However, the relationship between black postal employment and city-level segregation is only half as large as the baseline estimate (column 3). Black postal employment appears to be 
particularly affected by segregation between the city and its suburbs. We prefer to use the metropolitan-wide measure when it is available. For an accurate over-time comparison, we imagine "inflating" the 1940 and 1950 coefficients by the ratio between metropolitan- and citylevel estimates in $1970(1.857=0.117 / 0.063$; Table 7 , columns 1 and 3$)$. The resulting coefficients still imply a doubling of the relationship between segregation and black postal employment between 1950 and $1960 .{ }^{24}$

Higher black postal employment in segregated areas is partially offset with lower postal employment among non-blacks (Table 2, row 1). Suburbanization - and the associated increase in residential segregation - may have deterred whites from applying for centrally-located postal work. The fourth column separates an area's level of segregation in 1970 into the city's initial segregation level in 1940 and changes to that level between 1940 and 1970. Because the growth of the suburbs was, for the most part, a postwar phenomenon, the initial level of segregation is less likely to be determined by white suburbanization. We find that both components of segregation have equally large effects on the probability of black postal employment in 1970, casting doubt on explanations based on white residential location alone. More likely, with inelastic labor demand at the post office, blacks in close proximity to postal processing facilities simply outbid whites for available jobs.

Segregation is associated with a number of city characteristics that may affect postal employment. Segregated cities are larger, both in land area and population and, in 1970, had higher median family income and a lower poverty rate; higher black population share; higher mobility rates, measured as the share of the population living in the same house in 1965 and 1970; lower January and July temperatures; and fewer workers employed in construction or in

\footnotetext{
${ }^{24}$ The implied coefficients are 0.019 in $1940(=0.010 \cdot 1.857$; Table 2, column 1$)$ and 0.061 in $1950(=0.033 \cdot 1.857$; Table 2, column 2).
} 
business, repair and personal services. ${ }^{25}$ When we included the interaction of each of these potentially confounding factors in turn, the coefficient on the main segregation interaction remained statistically significant and varied between 0.106 and 0.138 . Only two of these factors were independently associated with black postal employment - the black population share and the share of workers employed in construction or business services; regressions with these variables included on the right hand side are reported in the last two columns of Table 7.

Selective migration could explain the attenuation in the coefficient of interest between 1970 and 2000. In particular, if skilled blacks left segregated cities after 1970, those remaining might not score high enough on the civil service exam to secure employment with the postal service (Ananat, 2007). The first panel of Table 8 re-runs our main specification for both a sample of young adults (age 18-30), the age group whose location is most likely to be exogenously determined by their city of birth, and for a comparison group of adults 31 and older (O'Regan and Quigley, 1996). Although the magnitudes are somewhat different, we find the same time series pattern in both sets of coefficients: no relationship between segregation and postal employment in 1940, a large positive effect in 1970, and a smaller but still positive effect in 2000. The decline between 1970 and 2000 is similar in percentage terms for both young and older adults, which does not support the sorting hypothesis.

Finally, we would expect the lack of jobs within close proximity to one's neighborhood to be a larger barrier to employment among the less educated who may be less adept at gathering information about job openings. The second panel of Table 8 divides the sample into high school dropouts and adults with at least a high school degree. Among blacks, the better educated group

\footnotetext{
${ }^{25}$ Residential segregation is not correlated with the share of a city's population that is foreign-born or of Spanish heritage; the average level of educational attainment of its residents; the share of its residents that commute by public transportation; the number of police officers or serious crimes per capita; or the share of its housing units that are single family or owner occupied.
} 
is four times more likely to work for the post office. However, relative to the mean, the positive effect of segregation on postal employment is twice as strong for the less educated group in 1970. By 2000, not only had the effect of segregation on postal employment declined for both groups, but the gap between the two disappeared. We see this as further evidence that the importance of job access in explaining black occupational choice has declined over time.

\section{Concluding Remarks}

The spatial mismatch hypothesis posits that as firms relocated to the suburbs, black neighborhoods grew increasingly isolated from job opportunities. This paper focuses on one large employer that has remained in downtown areas - the U.S. Postal Service. A significant fraction of postal facilities were located in central cities during the era of railroad mail delivery and, for largely bureaucratic reasons, remain in place today. If job accessibility matters, we should see blacks substituting towards postal work as other employment opportunities leave the city. This response should be particularly strong in segregated areas, where black neighborhoods tend to be clustered near the central business district.

We find that relative black postal employment was an increasing function of segregation from 1960 onward. Black employment shifted towards the post office at precisely the time when other "good jobs," such as those in manufacturing, were leaving central cities, but before fair housing laws opened the suburbs to middle class black residents. In addition, this pattern is observed only for non-mail carriers, most of whom work in downtown areas, not for mail carriers who are distributed more evenly around the metropolitan area. More recently, the relationship between black postal employment and segregation has been declining, but has not entirely disappeared. This timing suggests that spatial mismatch has an economic history; that is, 
spatial mismatch was once a factor in black employment outcomes but has become less important over time.

This paper has concentrated on the effect of segregation on black occupational choice. It would also be of interest to determine if the continued presence of postal facilities in the vicinity of black neighborhoods has spillover effects on other types of employment, or perhaps has kept (some) African-Americans in downtown areas who otherwise would have moved to the suburbs. In addition, we have also presumed that the centralized nature of mail processing and distribution is largely exogenous, or at least pre-determined by the history of railway mail. However, it is clear that strong unions or local government officials have managed to keep facilities centralized in some areas, but not in others. Analysis of the political economy of these location decisions may shed further light on the perceived benefits (and costs) of postal work to African-American communities. 


\section{Bibliography}

Ananat, Elizabeth Oltmans. "“The Wrong Side of the Track(s): Estimating the Causal Effects of Racial Segregation on City Outcomes.” NBER Working Paper 13343, August 2007.

Baum-Snow, Nathaniel. "Urban Employment Decentralization and Innovations to the Transportation Infrastructure.” Working Paper, 2007.

Becker, Gary. The Economics of Discrimination. Chicago: University of Chicago Press, 1971.

Brooks, Richard R. W. "Covenants and Conventions.” Law and Economics Research Paper Series, Northwestern University School of Law, No. 02-8, 2002.

Bureau of Labor Statistics, Occupational Outlook Handbook, 2006-07 Edition, Postal Service Workers, http://www.bls.gov/oco/ocos141.htm.

Collins, William J. and Robert A. Margo. "Residential Segregation and Socioeconomic Outcomes: When Did Ghettos Go Bad?” Economics Letters, 69, 2000, pp. 239-243.

Collins, William J. "The Housing Market Impact of State-Level Anti-Discrimination Laws, 1960-1970.” Journal of Urban Economics, 55(3), 2004, pp. 534-564.

Cutler, David M. and Edward L. Glaeser. “Are Ghettos Good or Bad?” Quarterly Journal of Economics, 112(3), August 1997, pp. 827-872.

Cutler, David, Edward L. Glaeser and Jacob Vigdor. "The Rise and Decline of the American Ghetto.” Journal of Political Economy. 107(3), 1999, pp. 455-506.

Downs, Anthony. "Alternative Futures for the American Ghetto.” Daedalus, Fall 1968, pp. 1331-1378.

DuBois, W.E.B. The Philadelphia Negro: A Social Study. New York: Schocken Books, 1967 (originally published, 1899).

Ellwood, David T. "The Spatial Mismatch Hypothesis: Are There Teenage Jobs Missing in the Ghetto?" in The Black Youth Employment Crisis, Richard B. Freeman and Harry J. Holzer, eds. Chicago: University of Chicago Press, 1986.

Farley, Reynolds. "The Urbanization of Negroes in the United States.” Journal of Social History, 1, 1968, pp. 241-58. 
Fogelson, Robert M. Downtown: It's Rise and Fall, 1880-1950. New Haven: Yale University Press, 2001.

Frazier, E. Franklin. The Negro in the United States. New York: Macmillan, 1957 (rev. ed.).

Gabriel, Stuart A., and Stuart S. Rosenthal. "Commutes, Neighborhood Effects, and Earnings: An Analysis of Racial Discrimination and Compensating Differentials." Journal of Urban Economics, 40(1), 1996, pp. 61-83.

Galster, George C. "On the Measurement of Metropolitan Decentralization of Blacks and Whites." Urban Studies, 21, 1984, pp. 465-470.

Glaeser, Edward L. and Matthew E. Kahn, "Decentralized Employment and the Transformation of the American City," Brookings/Wharton Papers on Urban Affairs, 2001, pp. 1-63.

Gosnell, Harold F. Negro Politicians: The Rise of Negro Politics in Chicago. Chicago: University of Chicago Press, 1935.

Harris, Abram L. The Negro as Capitalist. Philadelphia: The American Academy of Political and Social Sciences, 1936.

Hellerstein, Judith K., David Neumark and Melissa McInerney. "Spatial Mismatch or Racial Mismatch.” NBER Working Paper 13161, June 2007.

Ihlanfeldt, Keith R. and David L. Sjoquist, "The Impact of Job Decentralization on the Economic Welfare of Central City Blacks.” Journal of Urban Economics, 26, 1989, pp. 110-130.

Jackson, Kenneth T. Crabgrass Frontier: The Suburbanization of the United States. New York: Oxford University Press, 1985.

Kain, John F. "Housing Segregation, Negro Employment and Metropolitan Decentralization." Quarterly Journal of Economics, 82(2), 1968, pp. 175-197.

Kain, John F. and Joseph J. Persky. “Alternatives to the Gilded Ghetto.” Public Interest, 14, 1969, pp. 74-87.

Levine, Charles H. "Black Entrepreneurship in the Ghetto: A Recruitment Strategy." Land Economics, 48(3), 1972, pp. 269-273.

Massey, Douglas and Nancy Denton, American Apartheid: Segregation and the Making of the Underclass, Harvard University Press, 1993.

Myrdal, Gunnar. An American Dilemma: The Negro Problem and Modern Democracy. New York: Pantheon Books, 1962 (ori. pub. 1944). 
O'Regan, Katherine M. and John M. Quigley. "Where Youth Live: Economic Effects of Urban Space on Employment Prospects.” Urban Studies, 35(7), 1996, p. 1187-1205.

The Postal Directory 2007. Boyds, MD: Sedgwick Publishing Co.

Raphael, Steven. "The Spatial Mismatch Hypothesis and Black Youth Joblessness: Evidence from the San Francisco Bay Area." Journal of Urban Economics, 43, 1998, p. 79-111.

Rogers, Cynthia L. "Job Search and Unemployment Duration: Implications for the Spatial Mismatch Hypothesis.” Journal of Urban Economics, 42, 1997, p. 109-132.

Ross, Stephen L. "Racial Differences in Residential and Job Mobility: Evidence Concerning the Spatial Mismatch Hypothesis." Journal of Urban Economics, 43, 1998, p. 112-135.

Ross, Stephen L. and John Yinger. The Color of Credit: Mortgage Discrimination, Research Methodology, and Fair-Lending Enforcement. Cambridge: MIT Press, 2002.

Rubio, Philip F. 'There's Always Work at the Post Office': African Americans Fight for Jobs, Justice, and Equality at the United States Post Office, 1940-1971. Unpublished dissertation, Duke University, 2006.

Ruggles, Stephen, et al. Integrated Public Use Microdata Series: Version 4.0 [Machinereadable database]. Minneapolis, MN: Minnesota Population Center, 2008.

Stuart, Guy. Discriminating Risk: The US Mortgage Lending Industry in the Twentieth Century. Ithaca: Cornell University Press, 2003.

Sugrue, Thomas A. The Origins of the Urban Crisis: Race and Inequality in Postwar Detroit. Princeton: Princeton University Press, 1996.

Taeuber, Karl E. and Alma F. Taeuber. Negros in Cities. Chicago: Aldine Press, 1965.

Taylor, D. Brian, and Paul M. Ong. "Spatial Mismatch or Automobile Mismatch? An Examination of Race, Residence and Commuting in U.S. Metropolitan Areas." Urban Studies, 32(9), 1995, pp. 1453-73.

United States Postal Service. 2003. The United States Postal Service: An American History, 1775-2002. Washington, D.C.: United States Postal Service.

Warner, Sam Bass Jr. Streetcar Suburbs: The Process of Growth in Boston, 1870-1900. Cambridge: Harvard University Press, 1978.

Weinberg, Bruce A. "Black Residential Segregation and the Spatial Mismatch Hypothesis." Journal of Urban Economics. 48, 2000, pp. 110-134. 
Weinberg, Bruce A. "Testing the Spatial Mismatch Hypothesis Using Inter-City Variations in Industrial Composition." Regional Science and Urban Economics, 34(5), 2004, pp. 505-532.

Wilson, William Julius, The Truly Disadvantaged: The Inner City, the Underclass, and Public Policy, University of Chicago, 1987.

Woodson, Carter G. The Negro Professional Man and the Community. New York: Negro Universities Press, 1934. 
Figure 1: Employment in the postal service and the intrinsic public sector by race, 1900-2000

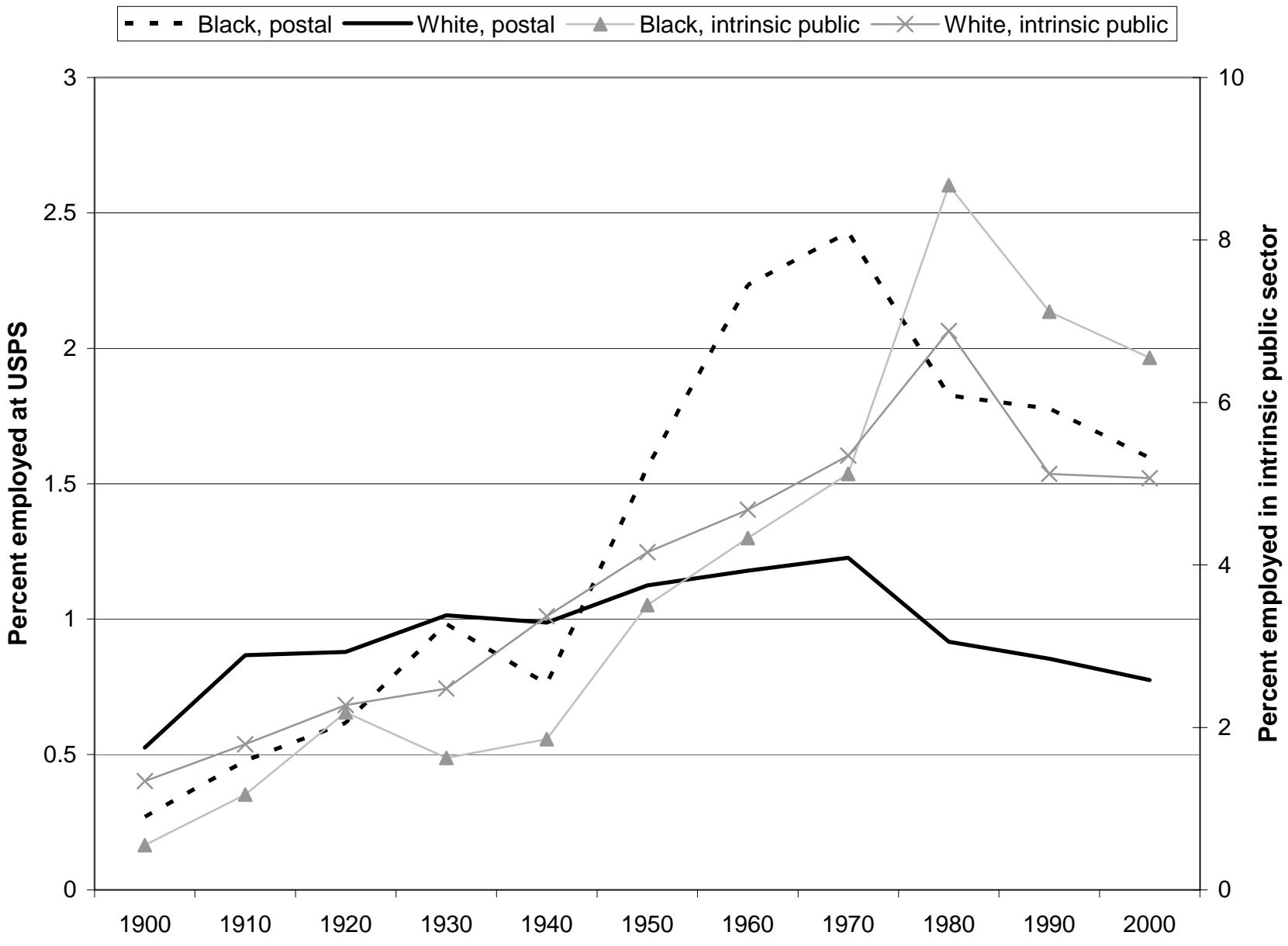

Notes: The data underlying this figure is presented in Appendix Table 1 and is described in its notes. 
Figure 2: The share of the labor force employed by the postal service by metropolitan area and race, 1970

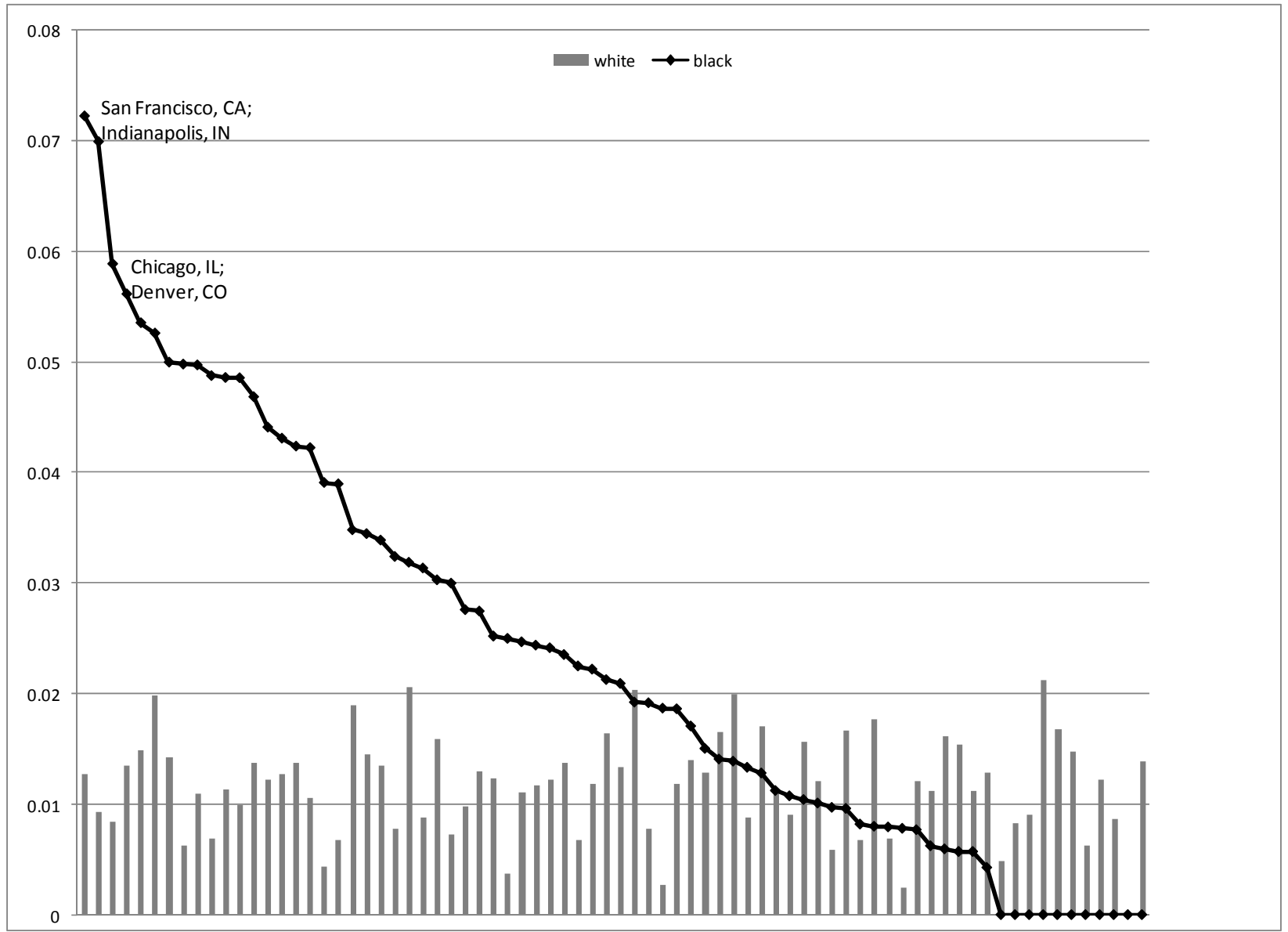

Notes: Each dot or bar represents the share of full-time, full-year employees working for the postal service by race. The figure portrays the 76 metropolitan areas that contain at least 50 black observations meeting the sample criteria in 1970. Metropolitan areas are arrayed from highest black postal share to lowest. 
Figure 3: Racial residential segregation and the differential probability of being employed in the postal service, 1970

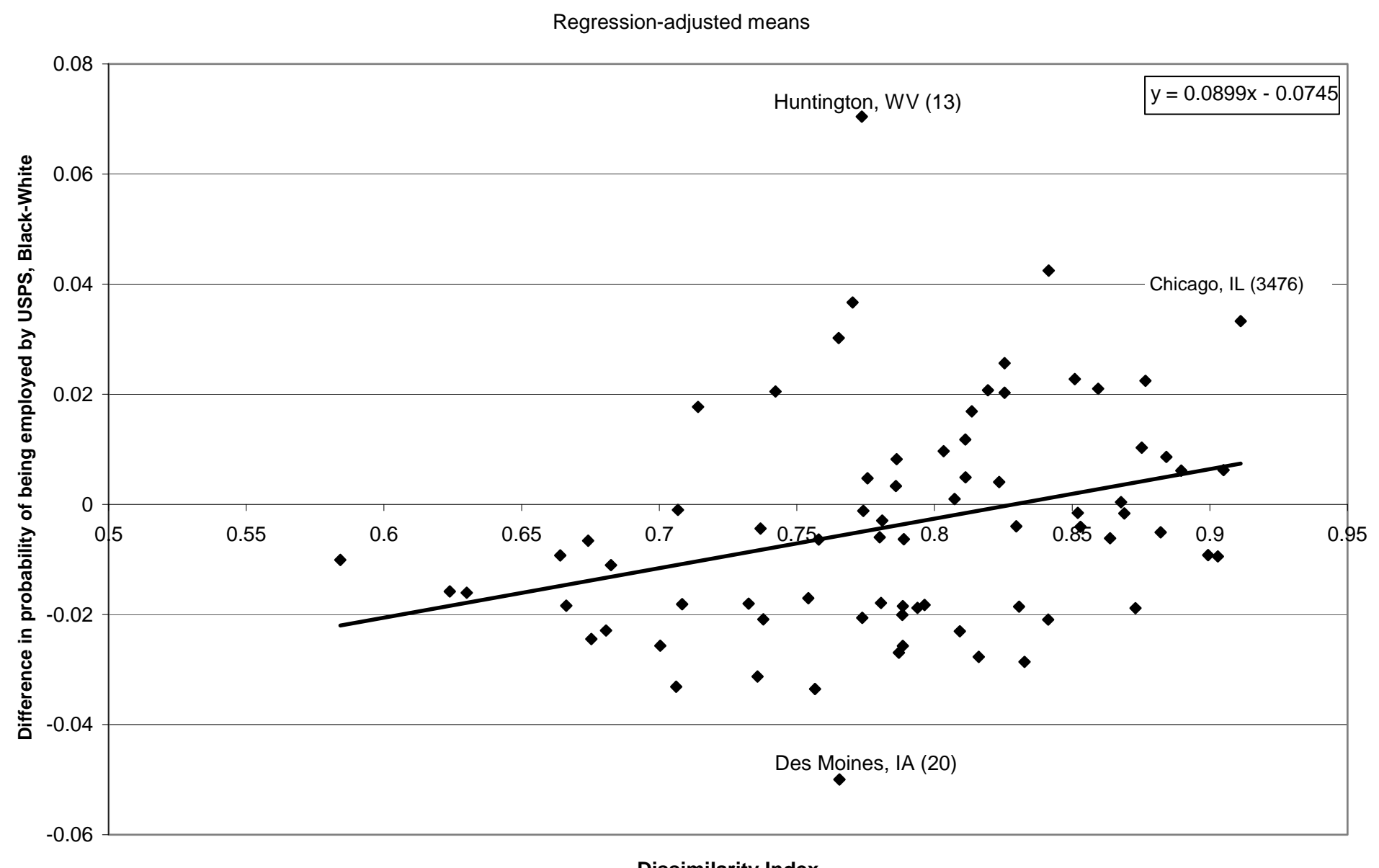

Note: Each dot represents one of the 74 metropolitan areas with available segregation data in 1970. The differential probability of postal employment (black versus white) is regression-adjusted for a series of individual characteristics. Sample restrictions and the set of control variables are listed in the notes to Table 2. 
Table 1: The location of the typical postal job, 1970 and 2000

\begin{tabular}{lc|lc}
\hline $\begin{array}{l}\text { A. Place of work, 1970 Census } \\
\text { Class of worker }\end{array}$ & \% in center city & B. Postal processing centers, 2000 & \\
\hline Postal work, non-carrier & 70.87 & Share in center city & 78.97 \\
Mail carrier & 55.56 & $\begin{array}{l}\text { Average \% black in neighborhood } \\
\text { (County, \% black) }\end{array}$ & 38.32 \\
Other, public sector & 56.23 & Highest \% black in neighborhood & 63.79 \\
Private sector & 53.34 & & \\
\hline
\end{tabular}

Panel A: Means are calculated for all metropolitan areas identified in the 1970 IPUMS. Mail carriers are classified using the 1950 occupation codes (=335). Public sector employees are identified from the class of worker variable. Panel B: Neighborhood characteristics for 237 postal Processing and Distribution Centers (P\&DCs) whose street addresses are included in the 2007 Postal Directory. The facility's neighborhood is defined as its own Census tract and all adjacent tracts. Means are weighted by the black population share in the county. 
Table 2: Racial residential segregation and the probability of postal employment, 1940-2000

Dependent variable $=1$ if employed at USPS

\begin{tabular}{|c|c|c|c|c|c|c|}
\hline Sample & 1940 & 1950 & 1970 & 1980 & 1990 & 2000 \\
\hline \multicolumn{7}{|c|}{ A. All available areas; Metropolitan area fixed effects; overall $\mathrm{R}^{2}=0.01$} \\
\hline Segregation & $\begin{array}{c}0.004 \\
(0.008)\end{array}$ & $\begin{array}{l}-0.013 \\
(0.007)\end{array}$ & $\begin{array}{l}-0.029 * \\
(0.009)\end{array}$ & $\begin{array}{l}-0.015^{*} \\
(0.005)\end{array}$ & $\begin{array}{l}-0.011^{*} \\
(0.005)\end{array}$ & $\begin{array}{l}-0.014^{*} \\
(0.005)\end{array}$ \\
\hline Seg $\cdot$ black & $\begin{array}{c}0.010 \\
(0.010)\end{array}$ & $\begin{array}{c}0.033 \\
(0.024)\end{array}$ & $\begin{array}{c}0.117 * \\
(0.034)\end{array}$ & $\begin{array}{c}0.057^{*} \\
(0.025)\end{array}$ & $\begin{array}{c}0.044 * \\
(0.012)\end{array}$ & $\begin{array}{c}0.042 * \\
(0.011)\end{array}$ \\
\hline $\mathrm{N}$ (individuals) & 97,131 & 40,593 & 188,067 & 347,817 & 375,870 & $2,249,487$ \\
\hline $\mathrm{N}(\mathrm{SMSA})$ & 45 & 47 & 74 & 229 & 238 & 243 \\
\hline \multicolumn{7}{|c|}{ B. All available areas; Metropolitan area-by-year fixed effects; overall $R^{2}=0.01$} \\
\hline Seg $\cdot$ black & $\begin{array}{c}0.016 \\
(0.011)\end{array}$ & $\begin{array}{c}0.034 \\
(0.024)\end{array}$ & $\begin{array}{c}0.123 * \\
(0.035)\end{array}$ & $\begin{array}{c}0.059 * \\
(0.026)\end{array}$ & $\begin{array}{c}0.045 * \\
(0.012)\end{array}$ & $\begin{array}{c}0.041 * \\
(0.011)\end{array}$ \\
\hline $\mathrm{N}$ (individuals) & 97,131 & 40,593 & 188,067 & 347,817 & 375,870 & $2,249,487$ \\
\hline $\mathrm{N}(\mathrm{SMSA})$ & 45 & 47 & 74 & 229 & 238 & 243 \\
\hline \multicolumn{7}{|c|}{ C. Balanced panel of areas; Metropolitan area fixed effects; overall $\mathbf{R}^{2}=0.01$} \\
\hline Segregation & $\begin{array}{c}0.004 \\
(0.008)\end{array}$ & $\begin{array}{l}-0.012 \\
(0.009)\end{array}$ & $\begin{array}{c}-0.027^{*} \\
(0.010)\end{array}$ & $\begin{array}{c}-0.015^{*} \\
(0.004)\end{array}$ & $\begin{array}{l}-0.006 \\
(0.006)\end{array}$ & $\begin{array}{l}-0.009 \\
(0.005)\end{array}$ \\
\hline Seg $\cdot$ black & $\begin{array}{c}0.008 \\
(0.009)\end{array}$ & $\begin{array}{c}0.029 \\
(0.025)\end{array}$ & $\begin{array}{l}0.102^{*} \\
(0.041)\end{array}$ & $\begin{array}{c}0.039 \\
(0.036)\end{array}$ & $\begin{array}{r}0.025 \\
(0.020)\end{array}$ & $\begin{array}{l}0.035 * * \\
(0.021)\end{array}$ \\
\hline $\begin{array}{l}\mathrm{N} \text { (individuals) } \\
\mathrm{N} \text { (SMSA) }\end{array}$ & $\begin{array}{c}97,131 \\
45\end{array}$ & $\begin{array}{c}39,809 \\
43^{\S}\end{array}$ & $\begin{array}{c}165,295 \\
45\end{array}$ & $\begin{array}{c}208,421 \\
45\end{array}$ & $\begin{array}{c}206,465 \\
45\end{array}$ & $\begin{array}{c}1,235,641 \\
45\end{array}$ \\
\hline
\end{tabular}

Notes: Standard errors are in parentheses and are clustered by metropolitan area. * indicates statistical significance at the five percent level or better. $* *$ indicates statistical significance at the ten percent level. The sample is restricted to full-time, full-year employees who are between the ages of 18-64 and are not currently enrolled in school, living in group quarters, in the armed services or in an agricultural industry. Full-time, fullyear is defined as working at least 40 hours a week and 40 weeks a year. 1960 is not included because IPUMS lacks metropolitan area of residence identifiers in that year.

In addition to listed fixed effects, the regressions include a fourth-order polynomial in age, dummies equal to one if the individual is black, married, a veteran, or foreign born, and five dummy variables for highest grade completed (using the IPUMS recode in 2000): 0-8, 9-11, 12, 13-15, and 16 years of schooling. All personal characteristics are interacted with the variable "black." When appropriate, regressions are weighted by the IPUMS person weight. The dissimilarity index, our measure of residential segregation, is available at the citylevel in 1940 and 1950 and at the metropolitan area-level from 1960 to 2000. $\S$ : Two of the metropolitan areas in the 1940 sample are not available in 1950. These are Augusta, GA and Des Moines, IA. The 1950 sample adds four metropolitan areas that are not available in 1940. These are:

Chattanooga, TN; Omaha, NE; Springfield, MA; and Wichita, KS. 
Table 3: Residential segregation and employment in the postal service in different samples

Dependent variable $=1$ if employed at USPS

Coefficients from the interaction of black $\cdot$ segregation index

\begin{tabular}{l|cc}
\hline & 1970 & 2000 \\
\hline 1. All adults & $0.090^{*}$ & $0.034^{*}$ \\
& $(0.034)$ & $(0.009)$ \\
1a. Men only & $0.077^{*}$ & $0.027^{*}$ \\
& $(0.033)$ & $(0.009)$ \\
2. + in labor force & $0.090^{*}$ & $0.034^{*}$ \\
& $(0.034)$ & $(0.009)$ \\
3. + work during year & $0.097^{*}$ & $0.035^{*}$ \\
& $(0.033)$ & $(0.009)$ \\
4. + work full year & $0.104^{*}$ & $0.036^{*}$ \\
& $(0.035)$ & $(0.010)$ \\
$5 .+$ work full year & $0.113^{*}$ & $0.041^{*}$ \\
& $(0.035)$ & $(0.011)$ \\
\hline
\end{tabular}

Notes: Standard errors are in parentheses and are clustered by metropolitan area. *: significant at 5 percent level or better. Regressions include all control variables listed in the notes to Table 2 . All rows include only individuals between the ages of 18-64 who are not currently enrolled in school, living in group quarters, in the armed services or in an agricultural industry. The additional sample restrictions are described in the first column and are cumulative. Full-time is defined as working at least 40 hours a week and full year is defined as working at least 40 weeks a year. 
Table 4: State-level residential segregation and employment in the postal service, 1940-2000

\begin{tabular}{|c|c|c|c|c|c|c|c|}
\hline \multicolumn{8}{|c|}{ Dependent variable $=1$ if employed at USPS } \\
\hline Sample & 1940 & 1950 & 1960 & 1970 & 1980 & 1990 & 2000 \\
\hline \multicolumn{8}{|c|}{ All available states; $\mathbf{R}^{2}=0.008$} \\
\hline Segregation & $\begin{array}{c}0.004 \\
(0.004)\end{array}$ & $\begin{array}{c}0.008 \\
(0.010)\end{array}$ & $\begin{array}{c}-0.028 * \\
(0.008)\end{array}$ & $\begin{array}{l}-0.029 * \\
(0.007)\end{array}$ & $\begin{array}{c}-0.012 * \\
(0.004)\end{array}$ & $\begin{array}{r}-0.010 * \\
(0.004)\end{array}$ & $\begin{array}{l}-0.007 \\
(0.004)\end{array}$ \\
\hline Segregation $\cdot$ black & $\begin{array}{l}-0.003 \\
(0.010)\end{array}$ & $\begin{array}{l}-0.011 \\
(0.023)\end{array}$ & $\begin{array}{c}0.118 * \\
(0.034)\end{array}$ & $\begin{array}{c}0.131 * \\
(0.031)\end{array}$ & $\begin{array}{c}0.063 * \\
(0.035)\end{array}$ & $\begin{array}{c}0.059 * \\
(0.016)\end{array}$ & $\begin{array}{c}0.035 * \\
(0.015)\end{array}$ \\
\hline $\mathrm{N}$ (individuals) & 166,669 & 71,856 & 299,012 & 320,886 & 482,572 & 585,963 & 978,985 \\
\hline $\mathrm{N}$ (states) & 33 & 31 & 40 & 42 & 44 & 47 & 47 \\
\hline \multicolumn{8}{|c|}{ Consistent set of states; $\mathbf{R}^{2}=\mathbf{0 . 0 0 8}$} \\
\hline Segregation & $\begin{array}{c}0.006 \\
(0.004)\end{array}$ & $\begin{array}{c}0.008 \\
(0.010)\end{array}$ & $\begin{array}{c}-0.027 * \\
(0.010)\end{array}$ & $\begin{array}{l}-0.027^{*} \\
(0.008)\end{array}$ & $\begin{array}{c}-0.011 * \\
(0.004)\end{array}$ & $\begin{array}{r}-0.010 * \\
(0.004)\end{array}$ & $\begin{array}{l}-0.007 \\
(0.004)\end{array}$ \\
\hline Segregation $\cdot$ black & $\begin{array}{l}-0.005 \\
(0.010)\end{array}$ & $\begin{array}{l}-0.011 \\
(0.023)\end{array}$ & $\begin{array}{c}0.133 * \\
(0.039)\end{array}$ & $\begin{array}{c}0.140 * \\
(0.035)\end{array}$ & $\begin{array}{c}0.058 \\
(0.041)\end{array}$ & $\begin{array}{c}0.053 * \\
(0.019)\end{array}$ & $\begin{array}{c}0.031 \\
(0.016)\end{array}$ \\
\hline $\mathrm{N}$ (individuals) & 162,603 & 71,856 & 276,644 & 300,386 & 439,202 & 527,242 & 869,434 \\
\hline $\mathrm{N}(\mathrm{SMSA})$ & 31 & 31 & 31 & 31 & 31 & 31 & 31 \\
\hline
\end{tabular}

Notes: Standard errors are in parentheses and are clustered by metropolitan area. *: significant at 5 percent level or better. Sample restrictions and additional control variables are listed in the notes to Table 2. 


\section{Table 5: Residential centralization, job access and employment in the postal service, 1980-1990}

Dependent variable $=1$ if employed at USPS

Coefficients from the interaction of black $\cdot$ metropolitan area characteristic

\begin{tabular}{|c|c|c|}
\hline & (1) & (2) \\
\hline $\begin{array}{l}\text { Panel A: } 1980 \\
\% \text { blacks live in city }\end{array}$ & $\begin{array}{l}0.024 * \\
(0.010)\end{array}$ & \\
\hline$\%$ employment in city & $\begin{array}{l}-0.024 \\
(0.014)\end{array}$ & $\begin{array}{c}0.162 \\
(0.090)\end{array}$ \\
\hline Segregation index & & $\begin{array}{c}0.174 * \\
(0.065)\end{array}$ \\
\hline Segregation index $\cdot \%$ employment & & $\begin{array}{l}-0.223 * * \\
(0.128)\end{array}$ \\
\hline $\begin{array}{l}\text { Panel B: } 1990 \\
\text { Centralization index }\end{array}$ & $\begin{array}{c}0.019 * \\
(0.006)\end{array}$ & $\begin{array}{c}0.003 \\
(0.008)\end{array}$ \\
\hline Segregation index & & $\begin{array}{l}0.043 * \\
(0.014)\end{array}$ \\
\hline
\end{tabular}

Notes: Standard errors are in parentheses and are clustered by metropolitan area. *: significant at 5 percent level or better. **: significant at 10 percent level. Sample restrictions and additional control variables are listed in the notes to Table 2 .

Panel A: The shares of population and employment that are located in the center city are calculated from the 'metro' and 'place of work' variables in the 1980 IPUMS. The regression includes 309, 206 individuals in the 128 metropolitan areas large enough for place of residence (central city versus suburb) to be reported.

Panel B: The centralization index was calculated by Cutler, Glaeser and Vigdor (1999). The index values are available at: http://trinity.aas.duke.edu/ jvigdor/segregation/index.html . 
Table 6: Residential segregation and public employment by job location, Seemingly unrelated regressions, 1940-2000

\begin{tabular}{l|ccc}
\multicolumn{3}{c}{ Coefficients from the interaction of black · segregation index } \\
\hline Dependent variables & 1940 & 1970 & 2000 \\
\hline Center city & 0.019 & $0.101^{*}$ & $0.030^{*}$ \\
Postal, non-carrier & $(0.013)$ & $(0.010)$ & $(0.003)$ \\
& & & $0.090^{*}$ \\
Other public, above median & --- & $(0.026)$ & $0.020^{*}$ \\
& & & $(0.007)$ \\
Suburbs & & 0.012 & $0.010^{*}$ \\
Postal, mail carrier & -0.009 & $(0.007)$ & $(0.002)$ \\
& $(0.009)$ & & $0.026^{*}$ \\
Other public, below median & --- & $-0.085^{*}$ & $(0.007)$ \\
\hline
\end{tabular}

Notes: Standard errors are in parentheses. *: significant at 5 percent level or better. Sample restrictions and additional control variables are listed in the notes to Table 2. Public sector occupations are classified according to the share of their white metropolitan employees who work in the central city. In the median occupation, the share of public employees who worked in the center city was 62.1 in 1970 and 52.7 in 2000 . Place of work information is not available in the 1940 Census to classify public occupations according to their central city share. 


\section{Table 7: Assessing the robustness of the relationship between segregation and postal employment, 1970}

Dependent variable $=1$ if employed at USPS

Coefficients from the interaction of black $\cdot$ metropolitan area characteristic

\begin{tabular}{|c|c|c|c|c|c|c|}
\hline & Base & Weighted & $\begin{array}{c}\text { Use City } \\
\text { Segregation }\end{array}$ & $\begin{array}{l}\text { Initial and } \\
\text { Change in }\end{array}$ & \multicolumn{2}{|c|}{$\begin{array}{c}\text { Additional RHS } \\
\text { variables }\end{array}$} \\
\hline Segregation & $\begin{array}{l}0.117 * \\
(0.034)\end{array}$ & $\begin{array}{c}0.104^{*} \\
(0.017)\end{array}$ & $\begin{array}{c}0.063 * \\
(0.023)\end{array}$ & & $\begin{array}{c}0.116^{*} \\
(0.033)\end{array}$ & $\begin{array}{c}0.138 * \\
(0.031)\end{array}$ \\
\hline Segregation, 1940 & & & & $\begin{array}{c}0.100 * \\
(0.041)\end{array}$ & & \\
\hline$\Delta$ segregation, $1940-70$ & & & & $\begin{array}{c}0.092 * \\
(0.032)\end{array}$ & & \\
\hline Black pop share & & & & & $\begin{array}{c}0.018 * \\
(0.009)\end{array}$ & \\
\hline Share LF in business & & & & & & $\begin{array}{c}0.258 * \\
(0.096)\end{array}$ \\
\hline Share LF in construct. & & & & & & $\begin{array}{l}-0.252^{*} \\
(0.127)\end{array}$ \\
\hline
\end{tabular}

Notes: Standard errors are in parentheses and are clustered by metropolitan area. *: significant at 5 percent level or better. Sample restrictions and additional control variables are listed in the notes to Table 2.

Column 1: Base specification equivalent to Table 2.

Column 2: Weight by inverse of number of observations by metropolitan area. Each area weighted equally.

Column 3: Measure dissimilarity among Census tracts in the central city rather than in the whole metropolitan area.

This index is equivalent to those used in 1940 and 1950.

Column 4: Includes only the 45 metropolitan areas that have available segregation data in 1940 and 1970.

Column 5: Share black is calculated from county data aggregated to the metropolitan area level.

Column 6: Share of central city's labor force employed either in business, repair and personal service or in construction. 
Table 8: Segregation and postal employment by age and education, 1940-2000

Dependent variable $=1$ if employed at USPS

Coefficients from the interaction of black $\cdot$ metropolitan area characteristic

\begin{tabular}{|c|c|c|c|c|}
\hline & & 1940 & 1970 & 2000 \\
\hline \multicolumn{5}{|l|}{ Age } \\
\hline \multirow[t]{3}{*}{$<=30$ years } & Coeff: & -0.018 & 0.067 & $0.029 *$ \\
\hline & & $(0.011)$ & $(0.047)$ & $(0.007)$ \\
\hline & Mean: & 0.004 & 0.022 & 0.010 \\
\hline \multirow[t]{3}{*}{$>=31$ years } & Coeff: & 0.020 & $0.133 *$ & $0.044 *$ \\
\hline & & $(0.016)$ & $(0.032)$ & $(0.012)$ \\
\hline & Mean: & 0.021 & 0.027 & 0.024 \\
\hline \multicolumn{5}{|l|}{ Education } \\
\hline \multirow[t]{3}{*}{$<=11$ years } & Coeff: & 0.014 & $0.073 *$ & 0.008 \\
\hline & & $(0.014)$ & $(0.017)$ & $(0.007)$ \\
\hline & Mean: & 0.010 & 0.012 & 0.005 \\
\hline \multirow[t]{3}{*}{$>=12$ years } & Coeff: & 0.000 & $0.165 *$ & $0.042 *$ \\
\hline & & $(0.046)$ & $(0.060)$ & $(0.012)$ \\
\hline & Mean: & 0.047 & 0.042 & 0.022 \\
\hline
\end{tabular}

Notes: Standard errors are in parentheses and are clustered by metropolitan area. *: significant at 5 percent level or better. Sample restrictions and additional control variables are listed in the notes to Table 2. Sample means for dependent variables are reported for blacks only. 


\section{Appendix Table 1: Employment in the postal service and public sector per 1,000 men by race, $1900-2000$}

\begin{tabular}{l|cccccc}
\hline & \multicolumn{3}{|c}{ Black } & \multicolumn{3}{c}{ White } \\
\cline { 2 - 6 } & All public & $\begin{array}{c}\text { Intrinsic } \\
\text { public }\end{array}$ & Postal & All public & $\begin{array}{c}\text { Intrinsic } \\
\text { public }\end{array}$ & Postal \\
\hline 1900 & & 5.83 & 2.70 & & 14.22 & 5.26 \\
1910 & & 12.15 & 4.78 & & 18.85 & 8.66 \\
1920 & & 21.87 & 6.17 & & 22.76 & 8.79 \\
1930 & & 16.95 & 9.83 & & 25.94 & 10.14 \\
1940 & 87.67 & 16.21 & 8,43 & 92.20 & 31.48 & 10.38 \\
1950 & 106.63 & 35.05 & 15.60 & 96.44 & 41.55 & 11.24 \\
1960 & 139.61 & 43.31 & 22.34 & 113.03 & 46.79 & 11.78 \\
1970 & 190.24 & 51.21 & 24.29 & 138.49 & 53.46 & 12.27 \\
1980 & 232.56 & 86.73 & 18.26 & 148.52 & 68.80 & 9.16 \\
1990 & 200.02 & 71.18 & 17.78 & 127.26 & 51.22 & 8.54 \\
2000 & 175.46 & 65.50 & 15.95 & 118.16 & 50.67 & 7.75 \\
\hline
\end{tabular}

Notes: The sample includes men between the ages of 18-64 who are not currently enrolled in school, living in group quarters, in the armed services or in an agricultural industry. Individuals must also be in the labor force. Between 1900-30, labor force participation is determined by holding a gainful occupation. Between 1940-2000, labor force participation is determined by employment status (at work or looking for work) during the census week.

'All public' includes anyone who is classified as working for the government in the 'class of worker' variable; this designation is available from 1940-2000. The intrinsic public sector includes only those workers whose industry is reported as: 906 (postal), 916 (federal, non-postal), 926 (state), 936 (local). In some years, SIC code 946 (level of government not identified) is reported, and is included in total intrinsic figure. 
Appendix Table 2: Black postal workers and the earnings distribution, 1940-2000

\begin{tabular}{|c|c|c|c|c|}
\hline & \multirow{2}{*}{$\begin{array}{l}\text { Mean weekly } \\
\text { wage, black } \\
\text { postal workers } \\
\text { (in \$1999) }\end{array}$} & \multirow{2}{*}{$\begin{array}{l}\text { Share of middle } \\
\text { class blacks who } \\
\text { work for USPS }\end{array}$} & \multicolumn{2}{|c|}{$\begin{array}{c}\text { Where does mean black postal } \\
\text { worker fall in wage distribution of... }\end{array}$} \\
\hline & & & All blacks & Non-blacks \\
\hline 1940 & 388.38 & 13.88 & 96.7 & 69.3 \\
\hline 1970 & 641.62 & 4.78 & 74.3 & 46.0 \\
\hline 2000 & 735.10 & 2.83 & 75.5 & 58.5 \\
\hline
\end{tabular}




\section{Appendix Table 3: Summary statistics for representative years}

\begin{tabular}{|c|c|c|c|c|}
\hline Variable & 1940 & 1970 & $1980 / 90$ & 2000 \\
\hline Segregation index & $\begin{array}{c}0.741 \\
(0.093)\end{array}$ & $\begin{array}{c}0.788 \\
(0.072)\end{array}$ & & $\begin{array}{c}0.502 \\
(0.131)\end{array}$ \\
\hline Black population share in city & $\begin{array}{c}0.126 \\
(0.117)\end{array}$ & $\begin{array}{c}0.151 \\
(0.140)\end{array}$ & & $\begin{array}{c}0.114 \\
(0.103)\end{array}$ \\
\hline Share postal & $\begin{array}{c}0.012 \\
(0.005)\end{array}$ & $\begin{array}{c}0.013 \\
(0.004)\end{array}$ & & $\begin{array}{c}0.009 \\
(0.003)\end{array}$ \\
\hline Share mail carrier & $\begin{array}{c}0.005 \\
(0.002)\end{array}$ & $\begin{array}{c}0.005 \\
(0.002)\end{array}$ & & $\begin{array}{c}0.004 \\
(0.001)\end{array}$ \\
\hline Share postal, non-carrier & $\begin{array}{c}0.007 \\
(0.004)\end{array}$ & $\begin{array}{c}0.008 \\
(0.004)\end{array}$ & & $\begin{array}{c}0.005 \\
(0.002)\end{array}$ \\
\hline Share public, all & $\begin{array}{c}0.100 \\
(0.043)\end{array}$ & $\begin{array}{c}0.154 \\
(0.068)\end{array}$ & & $\begin{array}{c}0.167 \\
(0.063)\end{array}$ \\
\hline Weekly wages, men only, $\$ 2000$ & $\begin{array}{l}396.91 \\
(60.36)\end{array}$ & $\begin{array}{l}845.15 \\
(78.16)\end{array}$ & & $\begin{array}{c}788.99 \\
(142.82)\end{array}$ \\
\hline Share blacks live in city, 1980 & & & $\begin{array}{c}0.624 \\
(0.292)\end{array}$ & \\
\hline Share employment in city, 1980 & & & $\begin{array}{c}0.553 \\
(0.159)\end{array}$ & \\
\hline Centralization index, 1990 & & & $\begin{array}{c}0.761 \\
(0.222)\end{array}$ & \\
\hline
\end{tabular}

Notes: The figures reported for weekly wages and idleness are means of metropolitan area-level averages. 